\title{
Video-assisted thoracoscopic thymectomy for early-stage thymoma: A review
}

\author{
Sadanori Takeo*, Fumihiro Shoji, Goji Toyokawa, Yuka Kozuma and Koji Yamazaki \\ Department of Thoracic Surgery, Clinical Research Institute, National Hospital Organization Kyushu Medical Center, Fukuoka, Japan
}

\begin{abstract}
Minimally invasive thoracoscopic surgery has become a popular technique to remove lung and mediastinal tumors. Video-assisted thoracic surgery (VATS) thymectomy has been performed for early-stage (Masaoka stages I/II) thymomas during the past two decades. Several reports have stated that VATS thymectomy for early stage thymomas appears safe and feasible. This technique is associated with a shorter hospital stay and has oncologic outcomes comparable with those of transsternal thymectomy. Other researchers have found no difference in the short-, mid-, or long-term prognosis between VATS and trans-sternal thymectomy. However, evaluation of the long-term oncologic outcomes of VATS thymectomy for early stage thymoma using national registries and randomized controlled trials is difficult because thymoma is a rare tumor. The present study was performed to investigate the history of, indications for, advantages and disadvantages of, and future potential problems associated with VATS thymectomy for treatment of early stage thymoma (Masaoka stages I/II).
\end{abstract}

\section{Introduction}

Thymoma is a common primary tumor that appears in the anterior mediastinum [1] and represents $50 \%$ of all anterior mediastinal tumors [2]. The incidence of thymomas, however, is low ( 0.15 cases per 100,000 person-years) [3].

According to the Japanese Association for Thoracic Surgery, video-assisted thoracic surgery (VATS) thymectomy was performed to treat $765(35.8 \%)$ of 1904 thymomas in 2013, and this number has increased each year since then [4]. The National Comprehensive Cancer Network (NCCN) guidelines [5], however, note that minimally invasive procedures are not yet routinely recommended because of the lack of long-term data. Additionally, VATS thymectomy should be performed in specialized centers by surgeons with experience using these techniques. We herein discuss the use of VATS thymectomy for early stage thymoma (Masaoka stages I/II) [6].

\section{Definitive surgery for early stage thymoma}

The most relevant prognostic factors for thymoma are the tumor stage [7-9], World Health Organization histologic type [7,8,10], and completeness of the resection [11-13]. The NCCN guidelines [5] state that the goal of open surgery is complete resection.

What, then, should be the extent of definitive surgery for treatment of clinically early-stage thymoma? Of 122 thymomas reviewed at the Massachusetts General Hospital [14], 28.5\% surgeries reported to be pathologically encapsulated showed microscopic evidence of true capsular invasion. Among other series involving $>100$ patients, an average of $81 \%$ of all recurrences were local, $9 \%$ were distant, and $11 \%$ involved both sites [15-18]. Among patients with recurrence, the pleural space or lung was involved in $58 \%$ (most often as a nodule under the parietal pleura), pericardium or mediastinum in $41 \%$, bone in $10 \%$, and liver in $8 \%$ [15-18]. This high incidence of local recurrence is a characteristic feature of thymomas.

Thymomas do not commonly metastasize to regional lymph nodes. A survey of 1327 patients from 115 specialized institutions certified by the Japanese Association of Chest Surgery revealed a 2\% (19/1064) incidence of lymph node metastases in patients with a thymoma ( $0.4 \%$ in stage I, $6.0 \%$ in stage III) [19]. However, how often nodes were examined in that study was unclear. Moreover, no routine policy appears to have been in place regarding whether (or which) nodes were biopsied or dissected. Detterbeck et al. [20] recommended removal of adjacent nodes and anterior mediastinal nodes even for stage I/II thymomas. Whether removal of lymph nodes is needed for early stage thymomas is controversial. However, it is at least necessary to perform complete resection for early stage thymoma.

\section{Complete resection of thymomas}

Zielinski et al. [21] and Ponseti et al. [22] reported that ectopic thymic tissues exist and possibly represent local recurrence (Figure 1). Scelsi et al. [23] also reported that remnants of the thymus may remain in extrathymic fat (pretracheal, anterior mediastinal, and costophrenic areas) and therefore recommended extended thymectomy. Removal of all ectopic thymic tissue is difficult, but at least the extrathymic fat must be resected.

Extended Thymectomy refers to en bloc resection from the superior to inferior pole of the thymus with the thymoma, including pretracheal fatty tissues and lymph nodes. The resection extends inward from the bilateral phrenic nerves, including the mediastinal pleura, and upward from costophrenic areas, including the fatty tissue; the pericardial leaves are also removed. The resection limits are the lower portion of the thyroid (top), pericardiophrenic fat (bottom), phrenic nerve (side), and pericardium (back). The resection include the cervical fat, perithymic fat, aortocaval groove fat, aortopulmonary window fat, and pericardiophrenic fat. However, Nakagawa et al. [24]

${ }^{\star}$ Correspondence to: Sadanori Takeo, Department of Thoracic Surgery, National Kyushu Medical Center, 1-8-1 Jigyohama, Chuo-ku, Fukuoka 810-8563, Japan, Tel: +92-852-0700; Fax: +92-846-8485, E-mail: sada@kyumed.jp

Key words: thymoma, VATS thymectomy, lift-up sternum, extended thymectomy, masaoka stage I/II

Received: June 20, 2019; Accepted: July 01, 2019; Published: July 04, 2019 


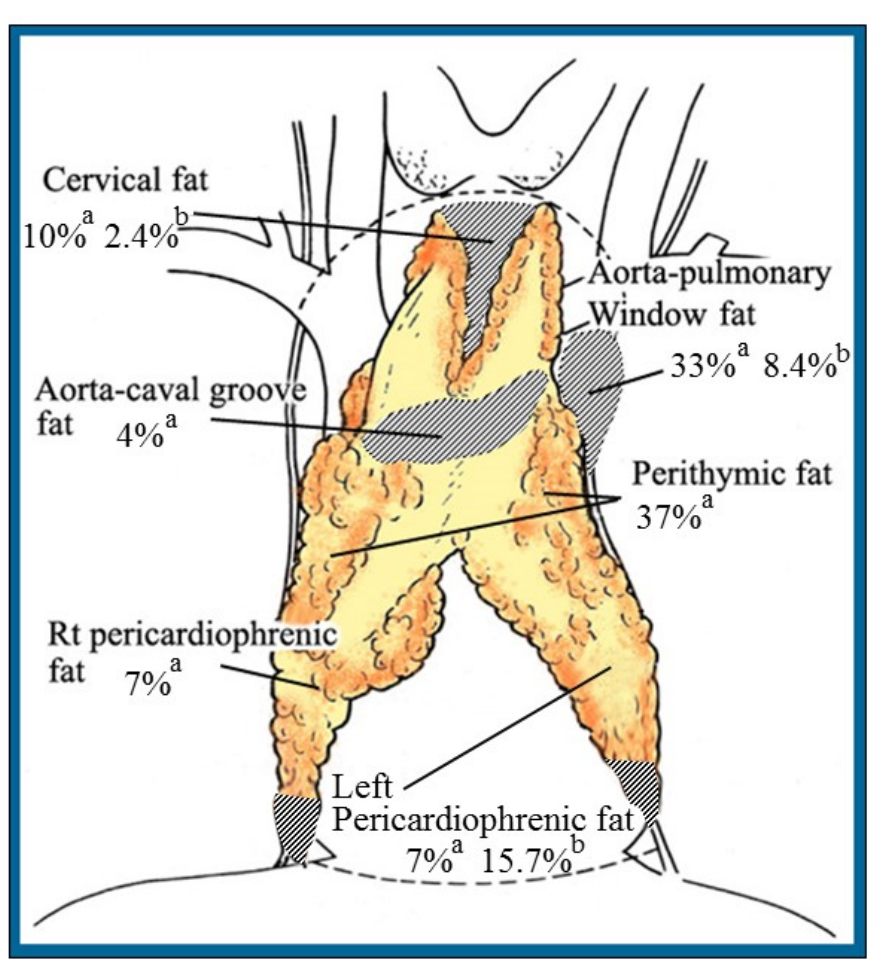

a: Zielinski [21] b: Ponseti [22]

Figure 1. Distribution and percentages of ectopic thymic tissue.

Rt- Right, ${ }^{a}$ From Zielinski et al. [21], ${ }^{b}$ From Ponseti et al. [22]

reported that there was no significance different in prognosis between thymomectomy (resection of thymoma with partial thymectomy) group and a thymothymomectomy (resection of thymoma with total thymectomy) group for stage I nonmyasthenic thymoma during open surgery. So, Extended Thymectomy may be needed for early-stage Thymoma with myasthenia gravis, but whether this procedure is needed for early-stage nonnyasthenic thymomas is controversial.

\section{Technical problems of VATS complete resection of thymoma}

The thymus is located in the anterior mediastinum immediately behind the sternum. The bilateral innominate veins, superior vena cava, and pericardium are located toward the back and the mediastinal pleura, bilateral intrathoracic arteries and veins, phrenic nerves, and lungs are located laterally. The most difficult point of thymectomy is the extent of excision required within the narrow working space. The surgeon must also be aware of the above-mentioned vessels and nerves near the thymus, especially the bilateral brachiocephalic veins, intrathoracic arteries and veins, thymic veins and arteries, and superior vena cava. The lungs and pericardium are also located in close proximity to the thymus, and the thymoma is sometimes firmly adherent to or invades the lung and/or pericardium. Each of these conditions contributes to the technical difficulty of VATS thymectomy in patients with thymomas.

\section{History of VATS thymectomy}

Throughout the history of developing various thoracoscopic approaches to the thoracic cavity, Landreneau et al. [25] were the first to report an approach from the left side of the thoracic cavity in 1992 and Yim et al. [26] from the right side of the thoracic cavity in 1995. Roviaro et al. [27] described a bilateral approach in 1993. Takeo et al. [28] reported a combined transcervical/subxiphoid and bilateral thoracic cavity approach in 2001, Mantegazza et al. [29] reported a cervical and bilateral approach in 2003, and Hsu et al. [30] reported a subxiphoid right-sided approach in 2004.

Recent advances in thoracoscopic technology have encouraged surgical experts to extend new approaches to more extensive procedures, including the treatment of thymic tumors. Several approaches have been established following these efforts. Several sternum-lifting methods (Figure 2) and several approaches to the tumor have been used to solve the problems associated with the narrow working space while maintaining a safe surgical environment.

Several one-sided approaches [31-37] have been described, as have unilateral and bilateral approaches [38-41], a transcervical approach $[42,43]$, bilateral access with an optional cervical incision [32], and a combined transcervical/subxiphoid and bilateral approach [35]. Finally, investigators have performed VATS thymectomy involving the combination of several approaches with or without sternum-lifting methods. Figure 3 shows the advantages and disadvantages of each approach with respect to anatomical difficulties.

The transcervical method is an easy approach with respect to the location of the pretracheal fat and brachiocervical vein, but it is difficult to resect large tumors or reach the lower portions of the thymus and pericardiophrenic fat. The incision for this method is long and located at the neck; a special apparatus is necessary. The mid-sternum technique can be used to easily approach the tumor, but it is difficult to distinguish the upper portion of the tumor from the brachiocervical vein. Additionally, this method is a difficult and dangerous approach within the thoracic space, even if thoracoscopy is used.

The trans-subxiphoid method provides easy access to the lower portion of the mediastinum but makes it difficult to resect the upper portion of the thymus and fat tissue. Resection of the thymic veins is also difficult using this method because the forceps lie parallel to the veins; thus, a special apparatus is required.

Sternum-lifting methods avoid these disadvantages, but whether these lifting methods are necessary remains unclear. We do not believe that a lifting method is necessary when thymectomy is the only procedure performed in a patient with a thymoma. When complete resection of thymoma is performed, however, a lifting method could be useful to secure the working space and maintain a safe surgical environment.

\section{Indications for VATS thymectomy}

Thoracoscopic resection of bulky or invasive thymomas remains technically challenging and controversial $[44,45]$. No consensus regarding the tumor size limit for VATS thymectomy has been established. Most investigators agree that the procedure is technically feasible for thymomas up to $5 \mathrm{~cm}$ in diameter [32,39,44,46,47]. We believe that the most important criteria for selecting VATS thymectomy depend more on the lack of tumor invasion to the great veins and pericardium than on the tumor size alone. The imaging characteristics that indicate tumor invasion have been widely studied $[48,49]$ and should be considered when selecting a surgical approach. Finally, VATS thymectomy should be indicated in patients with a Masaoka early-stage thymoma.

\section{Current state of VATS thymectomy compared with trans-sternal thymectomy}

We found several major series that reported the outcomes of VATS thymectomy for treatment of thymoma [36,38,41,44]. VATS thymectomy for early stage thymoma appears safe and feasible. This 

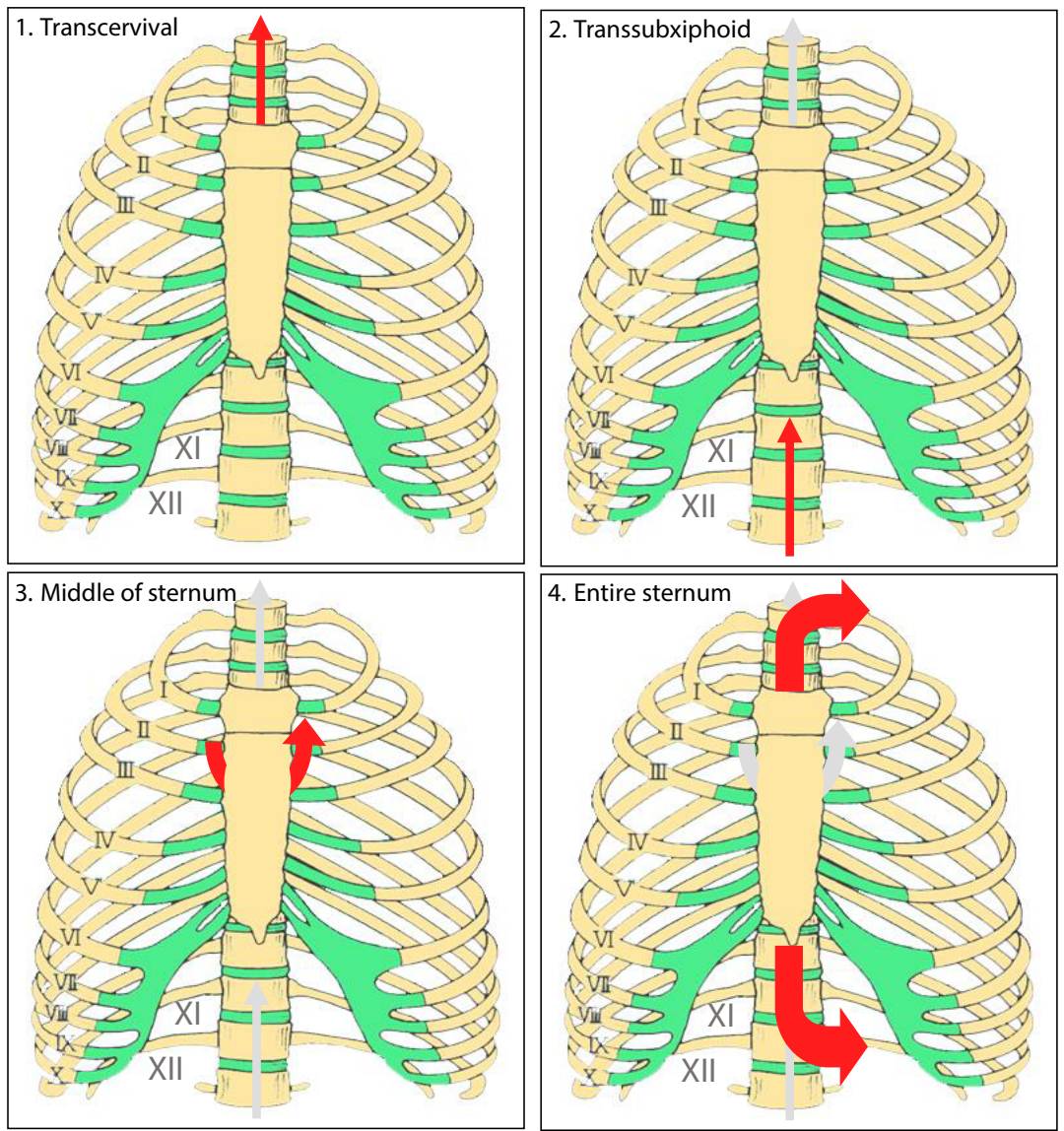

Figure 2. Several sternum-lifting methods

\begin{tabular}{|c|c|c|c|c|c|c|c|c|c|c|}
\hline & \multirow{2}{*}{$\begin{array}{l}\text { Working } \\
\text { space }\end{array}$} & \multicolumn{3}{|c|}{ Vessel } & \multicolumn{2}{|c|}{ Nerves } & \multirow[b]{2}{*}{ Lung } & \multirow[b]{2}{*}{ Pericardium } & \multirow{2}{*}{$\begin{array}{l}\text { Tumor } \\
\text { resection }\end{array}$} & \multirow[b]{2}{*}{ Anatomical problem } \\
\hline Approach & & $\begin{array}{l}\text { Brachiocephalic } \\
\text { vein }\end{array}$ & $\begin{array}{c}\text { Intrathoracic } \\
\text { vein and } \\
\text { artery }\end{array}$ & $\begin{array}{l}\text { Thymic } \\
\text { vein and } \\
\text { artery }\end{array}$ & $\begin{array}{l}\text { Phrenic } \\
\text { nerve }\end{array}$ & $\begin{array}{l}\text { Recurrent } \\
\text { nerve (left) }\end{array}$ & & & & \\
\hline Trans-cervical & Limited & Possible & Possible & $\begin{array}{l}\text { Possible } \\
\text { and } \\
\text { partially } \\
\text { difficult }\end{array}$ & Difficult & Good & Impossible & Difficult & $\begin{array}{l}\text { Limited to } \\
\text { small tumor }\end{array}$ & $\begin{array}{l}\text { Impossible to resect large tumor; } \\
\text { impossible to approach lower } \\
\text { portions of thymus }\end{array}$ \\
\hline $\begin{array}{l}\text { One-sided } \\
\text { trans- } \\
\text { intrathoracic }\end{array}$ & $\begin{array}{l}\text { Limited } \\
\text { but same } \\
\text { side: good } \\
\text { Other } \\
\text { side: } \\
\text { limited }\end{array}$ & $\begin{array}{l}\text { Possible and } \\
\text { partially difficult }\end{array}$ & $\begin{array}{l}\text { Same side: } \\
\text { good } \\
\text { Other side: } \\
\text { difficult }\end{array}$ & $\begin{array}{l}\text { Possible } \\
\text { and } \\
\text { partially } \\
\text { difficult }\end{array}$ & $\begin{array}{l}\text { Same side: } \\
\text { good } \\
\text { Other } \\
\text { side: } \\
\text { difficult }\end{array}$ & Impossible & Good & Good & $\begin{array}{l}\text { Needed } \\
\text { intercostal } \\
\text { thoracotomy; } \\
\text { postoperative } \\
\text { pain }\end{array}$ & $\begin{array}{l}\text { Impossible to resect cervical } \\
\text { portion; difficult to approach } \\
\text { another part of the thymus }\end{array}$ \\
\hline $\begin{array}{l}\text { Bilateral trans- } \\
\text { intrathoracic }\end{array}$ & Good & Possible & Good & Good & Good & Impossible & Good & Good & $\begin{array}{l}\text { Needed } \\
\text { intercostal } \\
\text { thoracotomy; } \\
\text { postoperative } \\
\text { pain }\end{array}$ & $\begin{array}{l}\text { Difficult to resect cervical } \\
\text { portion }\end{array}$ \\
\hline $\begin{array}{l}\text { Trans- } \\
\text { subxiphoid }\end{array}$ & Limited & $\begin{array}{l}\text { Possible and } \\
\text { partially difficult }\end{array}$ & $\begin{array}{l}\text { Possible and } \\
\text { partially } \\
\text { difficult }\end{array}$ & $\begin{array}{l}\text { Possible } \\
\text { and } \\
\text { partially } \\
\text { difficult }\end{array}$ & $\begin{array}{l}\text { Possible } \\
\text { and } \\
\text { partially } \\
\text { difficult }\end{array}$ & Impossible & Possible & Possible & $\begin{array}{l}\text { No need for } \\
\text { thoracotomy }\end{array}$ & $\begin{array}{l}\text { Difficult to resect cervical fat } \\
\text { portion completely; difficult to } \\
\text { approach the upper portion of } \\
\text { the left innominate vein }\end{array}$ \\
\hline $\begin{array}{l}\text { Our method } \\
\text { [33] }\end{array}$ & Good & Good & Good & Good & Good & Good & Good & Good & $\begin{array}{l}\text { No need for } \\
\text { thoracotomy }\end{array}$ & No problems \\
\hline
\end{tabular}

Figure 3. Advantages and disadvantages of each approach 
technique is associated with a shorter hospital stay and has oncological outcomes comparable with those of trans-sternal thymectomy $[31,34-38,40,41,47]$.

The completeness of resection of early stage thymomas with VATS thymectomy or trans-sternal thymectomy seems to be equally good $[32,38,41,44]$. VATS thymectomy is not yet recommended in the NCCN guidelines because the long-term prognosis has not been evaluated. However, several studies have found no difference in the short-term $[33,38,47]$, mid-term $[34,40,41]$, and long-term prognoses $[50,51]$ between VATS and trans-sternal thymectomy. Because portsite recurrence in association with VATS thymectomy has been reported [52], surgeons must take care to avoid contact between the tumor surface and port tracts during this procedure to prevent tumor cell implantation.

\section{Required standard for long-term prognosis of VATS thymectomy}

Three factors are important when considering the long-term prognosis: the overall survival rate, disease-free survival (DFS) rate, and recurrence rate. Among series investigating open surgery in $>200$ patients with stage I and II disease, the 5-year overall survival rate was $89-100 \%$ and $71-98 \%$, respectively, and the 10 -year overall survival rate was $80-100 \%$ and $60-98 \%$, respectively $[53,54]$. Several studies involving $>100$ patients found that the average 10-year DFS rate for stage I and II disease was $92 \%$ and $87 \%$, respectively [56-59].

Several authors have reported that during open surgery for treatment of thymoma, an average of 38\% (range, 19-58\%) of deaths were related to the primary tumor, $9 \%$ (range, 2-19\%) to postoperative causes, $22 \%$ (range, 16-27\%) to myasthenia gravis, 9\% (range, $2-19 \%$ ) to other autoimmune diseases, and $29 \%$ (range, $8-47 \%$ ) to unrelated causes (including other cancers) [53,56-59]. Patients rarely die of a thymoma-related cause. Hence, the DFS rate may be a better measure than the overall survival rate when determining the effectiveness of a surgical treatment.

Verley and Hollmann [60] reported that the mean time to recurrence following open surgery is 10 years in patients with a stage I thymoma and 3 years in patients with a stage II, III, or IV thymoma. A postoperative observation period of at least 10 years is needed for patients with a stage I thymoma. It is possible that overall survival and DFS rates of 15 years after VATS thymectomy for treatment of early stage thymoma will be recommended. However, because thymomas are rare tumors, it is needed to evaluate the long-term oncological outcomes of VATS thymectomy for early stage thymoma in national registries and randomized controlled trials.

\section{Conclusion}

If VATS thymectomy can be performed to the same extent as surgery with a trans-sternal incision, the functional and cosmetic advantages for the patient are unquestionable. Complete resection, defined as resection of all thymic tissue along with the thymoma itself, is also necessary for patients with a clinical early stage thymoma. VATS thymectomy could therefore be indicated in patients with a clinical early stage thymoma.

\section{Acknowledgment}

This work was presented as a keynote lecture at the 68th Annual Scientific Meeting of the Japanese Association for Thoracic Surgery.

\section{Conflict of interest}

Authors declare no conflicts of interest.

\section{References}

1. Strollo DC, Rosado de Christenson ML, Jett JR (1997) Primary mediastinal tumors. Part 1: tumors of the anterior mediastinum. Chest 112: 511-522. [Crossref]

2. Detterbeck FC, Zeeshan A (2013) Thymoma: current diagnosis and treatment. Chin Med J (Engl) 126: 2186-2191. [Crossref]

3. Engels EA, Pfeiffer RM (2003) Malignant thymoma in the United States: demographic patterns in incidence and associations with subsequent malignancies. Int J Cancer 105 : 546-551. [Crossref]

4. Masuda M, Kuwano H, Okumura M (2015) Thoracic and cardiovascular surgery in Japan during 2013: Annual report by The Japanese Association for Thoracic Surgery. Gen Thorac Cardiovasc Surg 63: 670-701. [Crossref]

5. NCCN clinical practice guidelines in oncology, Thymomas and Thymic Carcinomas Version 1.2016. Available from: https://www.nccn.org/professionals/physician_gls/ default.aspx.

6. Masaoka A (2010) Staging system of thymoma. J Thorac Oncol 5: S304-312. [Crossref]

7. Okumura M, Ohta M, Tateyama H, Nakagawa $\mathrm{K}$, Matsumura A, et al. (2002) The World Health Organization histologic classification system reflects the oncologic behavior of thymoma: a clinical study of 273 patients. Cancer 94: 624-632. [Crossref]

8. Chen G, Marx A, Chen WH, Yong J, Puppe B, et al. (2002) New WHO histologic classification predicts prognosis of thymic epithelial tumors: a clinicopathologic study of 200 thymoma cases from China. Cancer 95: 420-429. [Crossref]

9. Shimosato Y, Mukai K. Atlas of Tumor Pathology. Tumors of the Mediastinum. 3rd ed Armed Forces Institute of Pathology: Washington, D.C.1997.

10. Kondo K, Yoshizawa K, Tsuyuguchi M, Kimura S, Sumitomo M, et al. (2004) WHO histologic classification is a prognostic indicator in Thymoma. Ann Thorac Surg 77: 1183-1188. [Crossref]

11. Chalabreysse L, Roy P, Cordier JF, Loire R, Gamondes JP, et al. (2002) Correlation of the WHO schema for the classification of thymic epithelial neoplasms with prognosis: a retrospective study of 90 tumors. Am J Surg Pathol 26: 1605-1161. [Crossref]

12. Wilkins KB, Sheikh E, Green R. Patel M, George S, et al. (1999) Clinical and pathologic predictors of survival in patients with thymoma. Ann Surg 230: 562-572. [Crossref]

13. Schneider PM, Fellbaum C, Fink U, Bollschweiler E, Prauer HW (1997) Prognostic importance of histomorphologic subclassification for epithelial thymic tumors. Ann Surg Oncol 4: 46-56. [Crossref]

14. Qunitanilla-Marinez L, Wilkins EW Jr, Ferry JA, Harris NL (1993) Thymomamorphologic subclassification correlated with invasiveness and immunohistologic features: a study of 122 cases. Hum Pathol 24: 958-969. [Crossref]

15. Regnard JF, Magdeleinat P, Dromer C, Dulmet E, de Montpreville V, et al. (1996) Prognostic factors and long-term results after thymoma resection: a series of 307 patients. J Thorac Cardiovasc Surg 112: 376-384. [Crossref]

16. Blumberg D, Port JL, Weksler B, Delgado R, Rosai J, et al. (1995) Thymoma: a multivariate analysis of factors predicting survival. Ann Thorac Surg 60: 908-913. [Crossref]

17. Ruffini E, Mancuso M, Oliaro A, Casadio C, Cavallo A, et al. (1997) Recurrence of thymoma: analysis of clinicopathologic features, treatment, and outcome. $J$ Thorac Cardiovasc Surg 113: 55-63. [Crossref]

18. Maggi G, Giaccone G, Donadio M, Ciuffreda L, Dalesio O, et al. (1986) Thymomas. A review of 169 cases, with particular reference to results of surgical treatment. Cancer 58: 765-776. [Crossref]

19. Kondo K, Monden Y (2003) Lymphogenous and hematogenous metastasis of thymic epithelial tumors. Ann Thorac Surg 76: 1859-1864. [Crossref]

20. Detterbeck FC, Moran C, Huang J, Suster S, Walsh G, et al. (2011) Which Way is Up? Policies and Procedures for Surgeons and Pathologists Regarding Resection Specimens of Thymic Malignancy. J Thorac Oncol 6: S1730-8. [Crossref]

21. Zielinski M, Kuzdzal J, Szlubowski J, Soja J (2004) Comparison of late results of basic transsternal and extended transsternal thymectomies in the treatmentof myasthenia gravis. Ann Thorac Surg 78: 253-258. 
22. Ponseti JM, Gamez J, Vilallonga R, Ruiz C, Azem J, et al. (2008) Influence of ectopic thymic tissue on clinical outcome following extended thymectomy in generalized seropositive nonthymomatous myasthenia gravis. Eur J Cardiothorac Surg 34: $1062-$ 1067. [Crossref]

23. Scelsi R, Ferro MT, Scelsi L, Novellino L, Mantegazza R, et al. (1996) Detection and morphology of thymic remnants after video-assisted thoracoscopic extended thymectomy (VATET) in patients with myasthenia gravis. Int Surg 81:14-177. [Crossref]

24. Nakagawa K, Yokoi K, Nakajima J, Tanaka F, Maniwa Y, et al. (2016) Is Thymomectomy Alone Appropriate for Stage I(T1N0M0) Thymoma? Results of a Propensity-Score Analysis. Ann Thorac Surg 101: 520-526. [Crossref]

25. Landreneau RJ, Dowling RD, Castillo WM, Ferson PF (1992) Thoracoscopic resection of an anterior mediastinal tumor. Ann Thorac Surg 54: 142-144. [Crossref]

26. Yim AP, Kay RL, Ho JK (1995) Video-Assisted Thoracoscopic Thymectomy for Myasthenia Gravis. Chest 108: 1440-1443. [Crossref]

27. Roviaro GC, Rebuffat C, Varoli F, Vergani C, Maciocco M, et al. (1993) Videoendoscopic thoracic surgery. Int Surg 78: 4-9. [Crossref]

28. Takeo S, Sakada T, Yano T (2001) Video-assisted extended thymectomy in patients with thymoma by lifting the sternum. Ann Thorac Surg 71: 1721-1723. [Crossref]

29. Mantegazza R, Baggi F, Bernasconi P, Antozzi C, Confalonieri P, et al. (2003) Videoassisted thoracoscopic extended thymectomy and extended transsternal thymectomy (T-3b) in non-thymomatous myasthenia gravis patients: remission after 6 years of follow-up. J Neurol Sci 212: 31-36. [Crossref]

30. Hsu CP, Chuang CY, Hsu NY, Chen CY (2004) Comparison between the right side and subxiphoid bilateral approaches in performing video-assisted thoracoscopic extended thymectomy for myasthenia gravis. Surg Endosc 18: 821-824. [Crossref]

31. Maniscalco P, Tamburini N, Quarantotto F, Grossi W, Garelli E, et al. (2015) LongTerm Outcome for Early Stage Thymoma: Comparison between Thoracoscopic and Open Approaches. Thorac Cardiovasc Surg 63: 201-205. [Crossref]

32. Yuan ZY, Cheng GY, Sun KL, Mao YS, Li J, et al. (2014) Comparative study of videoassisted thoracic surgery versus open thymectomy for thymoma in one single center. $J$ Thorac Dis 6: 726-733. [Crossref]

33. Triviño A, Congregado M, Loscertales J, Cozar F, Pinos N, et al. (2015) Comparative Analysis of Video-assisted Thoracic Surgery Versus Open Resection for Early-stage Thymoma. Cir Esp 93: 466-471. [Crossref]

34. Manoly I, Whistance RN, Sreekumar R, Khawaja S, Horton JM, et al. (2014) Early and mid-term outcomes of trans-sternal and video-assisted thoracoscopic surgery for thymoma. Eur J Cardiothorac Surg 45: 187-193. [Crossref]

35. Tagawa T, Yamasaki N, Tsuchiya T, Miyazaki T, Morino S, et al. (2014) Thoracoscopic versus transsternal resection for early stage thymoma: long-term outcomes. Surg Today 44: 2275-2280. [Crossref]

36. Ye B, Tantai JC, Ge XX, Li W, Feng J, et al. (2014) Surgical techniques for early-stage thymoma: Video-assisted thoracoscopic thymectomy versus transsternal thymectomy. J Thorac Cardiovasc Surg 147: 1599-1603. [Crossref]

37. Jurado J, Javidfar J, Newmark A, Lavelle M, Bacchetta M, et al. (2012) Minimally Invasive Thymectomy and Open Thymectomy: Outcome Analysis of 263 Patients. Ann Thorac Surg 94: 974-982. [Crossref]

38. Kimura T, Inoue M, Kadota Y, Shiono H, Shintani Y, et al. (2013) The oncological feasibility and limitations of video-assisted thoracoscopic thymectomy for early-stage thymomas. Eur J Cardiothorac Surg 44: 214-218. [Crossref]

39. Odaka M, Akiba T, Mori S, Asano H, Marushima H, et al. (2013) Oncological outcomes of thoracoscopic thymectomy for the treatment of stages I-III thymomas. Interact Cardiovasc Thorac Surg 17: 285-290. [Crossref]

40. Pennathur A, Qureshi I, Schuchert MJ, Dhupar R, Ferson PF, et al. (2011) Comparison of surgical techniques for early stage thymoma: Feasibility of minimally invasive thymectomy and comparison with open resection. J Thorac Cardiovasc Surg 141: 694-701. [Crossref]
41. Sakamaki Y, Oda T, Kanazawa G, Shimokawa T, Kido T, et al. (2014) Intermediateterm oncologic outcomes after video-assisted thoracoscopic thymectomy for earlystage thymoma. J Thorac Cardiovasc Surg 148: 1230-1237. [Crossref]

42. Komanapalli CB, Cohen JI, Sukumar MS (2010) Extended Transcervical VideoAssisted Thymectomy. Thorac Surg Clin 20: 235-243. [Crossref]

43. Shiono H, Shigemura N, Okumura M (2008) Inclusion of the transcervical approach in video-assisted thoracoscopic extended thymectomy (VATET) for myasthenia gravis: a prospective trial. Surg Endosc 22:1135-1136. [Crossref]

44. Takeo S, Tsukamoto S, Kawano D, Katsura M (2011) Outcome of an original videoassisted thoracoscopic extended thymectomy for thymoma. Ann Thorac Surg 92: 20002005. [Crossref]

45. Agasthian T (2011) Can invasive thymoma be resected by video-assisted thoracoscopic surgery? Asian Cardiovasc Thorac Ann 19: 225-227. [Crossref]

46. Marulli G, Rea F, Melfi F, Schmid TA, Ismail M, et al. (2012) Robot-aided thoracoscopic thymectomy for early-stage thymoma: a multicenter European study. $J$ Thorac Cardiovasc Surg 144:1125-1132. [Crossref]

47. Liu TJ, Lin MW, Hsieh MS, Kao MW, Chen KC, et al. (2014) Video-Assisted Thoracoscopic Surgical Thymectomy to Treat Early Thymoma: A Comparison with the Conventional Transsternal Approach. Ann Surg Oncol. 21: 322-328. [Crossref]

48. Chen J, Weisbrod GL, Herman SJ (1988) Computed tomography and pathologic correlation of thymic lesions. J Thorac Imaging 3: 61-65. [Crossref]

49. Tomiyama N, Muller NL, Ellis SJ, Cleverley JR, Okumura M, et al. (2001) Invasive and noninvasive thymoma: distinctive CT features. J Comput Assist Tomogr 25: 388 393. [Crossref]

50. Maniscalco P, Tamburini N, Quarantotto F, Grossi W, Garelli E, et al. (2015) Longterm outcome for early stage thymoma: comparison between thoracoscopic and open approaches. Thorac Cardiovasc Surg 63:201-205. [Crossref]

51. Chao YK, Liu YH, Hsieh MJ, Wu YC, Chen TP, et al. (2015) Long-term outcomes after thoracoscopic resection of stage I and II thymoma: a propensity-matched study Ann Surg Oncol 22: 1371-1376. [Crossref]

52. Ishibashi H, Takasaki C, Okubo K (2015) Port-site recurrence after complete resection of stage I thymoma by video-assisted thoracoscopic surgery: report of a case. Surg Today 45: 232-234. [Crossref]

53. Kondo K, Monden Y (2003) Therapy for thymic epithelial tumors: a clinical study of 1,320 patients from Japan. Ann Thorac Surg 76: 878-84. [Crossref]

54. Maggi G, Casadio C, Cavallo A, Cianci R, Molinatti M, et al. (1991) Thymoma: results of 241 operated cases. Ann Thorac Surg 51: 152-156. [Crossref]

55. Detterbeck FC, Parsons AM (2004) Thymic Tumors. Ann Thorac Surg 77: 1860-1869. [Crossref]

56. Quintanilla-Martinez L, Wilkins EW Jr, Choi N, Efird J, Hug E, et al. (1994) Thymoma. Histologic subclassification is an independent prognostic factor. Cancer 74: 606-617. [Crossref]

57. Cowen D, Richaud P, Mornex F, Bachelot T, Jung GM, et al. (1995) Thymoma: Results of a multicentric retrospective series of 149 non-metastatic irradiated patients and review of the literature. FNCLCC trialists. Federation Nationale des Centres de Lutte Contre le Cancer. Radiother Oncol 34: 9-16. [Crossref]

58. Okumura M, Miyoshi S, Takeuchi Y, Yoon HE, Minami M, et al. (1999) Results of surgical treatment of thymomas with special reference to the involved organs. J Thorac Cardiovasc Surg 117: 605-613. [Crossref]

59. Ogawa K, Toita T, Uno T, Fuwa N, Kakinohana Y, et al. (2002) Treatment and prognosis of thymic carcinoma: a retrospective analysis of 40 cases. Cancer $94: 3115$ 3119. [Crossref]

60. Verley JM, Hollmann KH (1985) Thymoma. A comparative study of clinical stages, histologic features, and survival in 200 cases. Cancer 55: 1074-1086. [Crossref]

Copyright: (2019 Takeo S. This is an open-access article distributed under the terms of the Creative Commons Attribution License, which permits unrestricted use, distribution, and reproduction in any medium, provided the original author and source are credited. 